\title{
Fat City: Questioning the Relationship Between Urban Sprawl and Obesity
}

\author{
Jean Eid*十 \\ University of Toronto \\ Henry G. Overman*‡ \\ London School of Economics \\ Diego Puga*§ \\ Universitat Pompeu Fabra
Matthew A. Turner*II
University of Toronto

30 October 2006

\begin{abstract}
Авsтract: We study the relationship between urban sprawl and obesity. Using data that tracks individuals over time, we find no evidence that urban sprawl causes obesity. We show that previous findings of a positive relationship most likely reflect a failure to properly control for the fact the individuals who are more likely to be obese choose to live in more sprawling neighborhoods. Our results indicate that current interest in changing the built environment to counter the rise in obesity is misguided.
\end{abstract}

Key words: urban sprawl, obesity, selection effects JEL classification: I12, R14

\footnotetext{
${ }^{*}$ We are grateful to Eric Fischer, Holly Olson, Pat Rhoton, and Molly Shannon of the us Bureau of Labor Statistics for assisting us to gain access the Confidential Geocode Data of the National Longitudinal Survey of Youth. For helpful comments and suggestions we thank Vernon Henderson, Matthew Kahn and Andrew Plantinga. Funding from the Social Sciences and Humanities Research Council of Canada (Puga and Turner), the Center for Urban Health Initiatives (Eid), and the support of the Canadian Institute for Advanced Research (Puga) are gratefully acknowledged.

${ }^{\dagger}$ Department of Economics, University of Toronto, 150 Saint George Street, Toronto, Ontario M5s 3G7, Canada (e-mail: jean.eid@utoronto.ca; website: http://www. chass.utoronto.ca/ jeaneid/).

‡Department of Geography and Environment, London School of Economics, Houghton Street, London wC2A 2AE, United Kingdom (e-mail: h.g.overman@lse.ac.uk; website: http://cep.lse.ac.uk/ overman). Also affiliated with the Centre for Economic Performance and the Centre for Economic Policy Research.

§Universitat Pompeu Fabra, Ramon Trias Fargas, 25-27, 08005, Barcelona, Spain a (e-mail: diego.puga@upf .edu; website: http://diegopuga.org). Also affiliated with the Centre for Economic Policy Research and the Centre de Recerca en Economia Internacional.

II Department of Economics, University of Toronto, 150 Saint George Street, Toronto, Ontario M5s 3G7, Canada (e-mail: mturner@chass . utoronto. ca; website: http://www . economics . utoronto.ca/mturner/).
} 


\section{Introduction}

The prevalence of obesity in the us has increased dramatically over the last two decades. In the late 1970 's, $12.7 \%$ of men and $17 \%$ of women were medically obese. By 2000 these proportions had risen to $27.7 \%$ and $34 \%$ respectively (Flegal, Carroll, Ogden, and Johnson, 2002). Such a rise poses "a major risk for chronic diseases, including type 2 diabetes, cardiovascular disease, hypertension and stroke, and certain forms of cancer" (World Health Organization, 2003, p. 1), and has also been linked to birth defects, impaired immune response and respiratory function (American Obesity Association, 2002). Health spending on obesity-related illness in the us now exceeds that for smoking- or problem-drinking-related illnesses (Sturm, 2002). In short, obesity is one of today's top public health concerns.

Obesity rates have not increased at the same pace, nor reached the same levels, everywhere in the United States. For instance, between 1991 and 1998 the prevalence of obesity increased by $102 \%$ in Georgia but by only $11 \%$ in Delaware (Mokdad, Serdula, Dietz, Bowman, Marks, and Koplan, 1999). Similarly, while $30 \%$ of men and $37 \%$ of women in Mississippi were medically obese in 2000, the corresponding figures for Colorado were $18 \%$ and $24 \%$ respectively (Ezzati, Martin, Skjold, Hoorn, and Murray, 2006). Such large spatial differences in the incidence of obesity have led many to claim that variations in the built environment, by affecting exercise and diet, may have a large impact on obesity. For instance, compact neighborhoods may induce people to use their car less often than those where buildings are scattered. Similarly, neighborhoods where houses are mixed with a variety of local grocery stores and other shops may encourage people to walk more and eat healthier food than those where all land is devoted to housing. A growing and influential literature studies this connection between the built environment and obesity. Loosely, its main finding is that individuals living in sprawling neighborhoods are more likely to be obese than those who live in less sprawling neighborhoods. ${ }^{1}$ Evidence from some of these studies has prompted the World Health Organization, the us Centers for Disease Control and Prevention, the Sierra Club and Smart Growth America, among others, to advocate that city planning be used as a tool to combat the obesity epidemic. ${ }^{2}$ The vast sums that Americans spend on weight loss testify to the difficulty of changing the habits that affect weight gain. If changes to the built environment were indeed effective in affecting those habits, urban planning could thus be an important tool with which to curb the rise in obesity.

However, before we rush to re-design neighborhoods, it is important to note that a positive correlation between sprawl and obesity does not necessarily imply that sprawl causes obesity or that reducing sprawl will lead people to lose weight. For both genetic and behavioral reasons, individuals vary in their propensity to be obese. Many of the idiosyncratic characteristics that affect obesity may also affect neighborhood choices. For instance, someone with an idiosyncratic distaste for walking is both more likely to be obese and to prefer living where one can easily get around by car. For such individuals obesity is correlated with, but not caused by, the choice to live in a sprawling neighborhood. That is, we may observe more obesity in sprawling neighborhoods

\footnotetext{
${ }^{1}$ See, for example, Ewing, Schmid, Killingsworth, Zlot, and Raudenbush (2003), Giles-Corti, Macintyre, Clarkson, Pikora, and Donovan (2003), Saelens, Sallis, Black, and Chen (2003) and Frank, Andresen, and Schmid (2004).

${ }^{2}$ World Health Organization (2004), Gerberding (2003), Sierra Club (2000), McCann and Ewing (2003).
} 
because individuals who have a propensity to be obese choose to live in these neighborhoods. If such self-selection is important we can observe higher rates of obesity in sprawling neighborhoods even if there is no causal relationship between sprawl and obesity.

In this paper we examine whether the correlation between obesity and sprawl reflects the fact that individuals with a greater tendency to be obese self-select into sprawling neighborhoods. To this end, we use the Confidential Geocode Data of the National Longitudinal Survey of Youth 1979 (NLSY79) of the us Bureau of Labor Statistics to match a representative panel of nearly 6,000 individuals to neighborhoods throughout the United States. These data track each individual's residential address, weight, and other personal characteristics over time. $79 \%$ of these people move address at least once during our six year study period. These movers allow us to identify the effect of sprawl on weight, after controlling for individuals' propensity to be obese, by looking at whether a given individual gains weight when they move to a more sprawling neighborhood or if they lose weight when they move to a less sprawling one.

We focus on two key dimensions of the built environment that the existing literature suggests as potential determinants of obesity. First, we use 30-meter resolution remote-sensing land cover data from Burchfield, Overman, Puga, and Turner (2006) to measure 'residential-sprawl' as the extent to which residential development is scattered as opposed to being compact. Second, we use counts of retail shops and churches from us Census Bureau Zip Code Business Patterns data to measure the extent to which a neighborhood can be characterized as 'mixed-use'.

As in the existing literature, for men, we find a positive correlation between obesity and residential-sprawl and a negative correlation between obesity and mixed-use. However, the association between obesity and residential-sprawl does not persist after controlling for sufficiently detailed observable individual characteristics. This tells us that these observable characteristics explain both propensity to be obese and to live in a sprawling neighborhood. In contrast, we still see a negative correlation between mixed-use and obesity, even after controlling for these observable individual characteristics. However, once we take advantage of the panel dimension of our data to control for unobserved propensity to be obese, the correlation between obesity and mixed-use also vanishes. For women, the cross-sectional correlation between obesity and both residential-sprawl and mixed-use is weaker than for men. However, in some regressions controlling for a small set of observable individual characteristics we do find a negative correlation between obesity and residential-sprawl. As in the case of men, once we take advantage of the panel dimension of our data to control for unobserved propensity to be obese, we cannot find any evidence of a positive relationship between obesity and residential-sprawl nor of a negative relationship between obesity and mixed-use. Our results strongly suggest that neither residential-sprawl nor a lack of mixed-use causes obesity in men or women, and that higher obesity rates in 'sprawling' areas are entirely due to the self-selection of people with a propensity for obesity into these neighborhoods.

The rest of the paper is structured as follows. Section 2 provides an overview of the literature. Section 3 then describes our empirical strategy. Section 4 describes our data while section 5 presents results. Finally, section 6 concludes. 


\section{Literature}

In this section, we review studies that consider whether individuals living in sprawling neighborhoods are more likely to be obese than those who live in less sprawling neighborhoods. We also discuss the novelties of our approach. It is worth noting that none of the studies we discuss claims that sprawl is one of the main drivers of the long-term trend towards rising body weight. ${ }^{3}$ Instead, they suggest that differences in the characteristics of the built environment may help explain the large observed spatial differences in the prevalence of obesity, and imply that urban planning can be used as a policy lever to reduce the incidence of obesity.

Ewing et al. (2003) combine obesity and demographic data from the Behavioral Risk Factor Surveillance System surveys with a county-level composite "sprawl index" developed in Ewing, Pendall, and Chen (2002). After controlling for some demographic characteristics, they find that living in a sprawling county is associated with a small but significant increase in obesity. This finding is suggestive, but is subject to three important criticisms. Most fundamentally, Ewing et al. (2003) do not address the problem of neighborhood self-selection on the basis of unobservable propensities to be obese. ${ }^{4}$ Hence, they do not determine whether higher obesity rates are due to a tendency of people predisposed to obesity to choose certain neighborhoods, or whether sprawling landscapes actually cause obesity. Secondly, Ewing et al. (2003) work with very coarse spatial data: counties in the us are very large relative to any sensible definition of a residential neighborhood. Finally, Ewing et al. (2003) use a measure of sprawl that is constructed as an average of several variables. Given that some of these variables are known to be weakly correlated with each other (Glaeser and Kahn, 2004, Burchfield et al., 2006), it is not clear which aspect of urban planning they have in mind as a policy lever to tackle obesity.

Giles-Corti et al. (2003), Saelens et al. (2003) and Frank et al. (2004) all address these last two issues by considering more finely-defined neighborhoods and by looking at various neighborhood characteristics independently of each other. This tighter definition of neighborhoods comes at the cost of a focus on very small geographical study areas (Perth, two neighborhoods in San Diego, and Atlanta, respectively). Moreover, like Ewing et al. (2003), these authors do not address the problem of self-selection. Again, this makes it impossible to infer a causal link from the built environment to obesity. As Frank et al. (2004) acknowledge "[t]o date, little research has been performed that uses individual-level data and objective measures of the built environment at a scale relevant to those individuals. Even though we address some of these limitations, the current cross-sectional study also cannot show causation." (Frank et al., 2004, p. 88).

In a contemporaneous study, Plantinga and Bernell (2005) attempt to correct for the sorting of people into neighborhoods. Using cross-sectional data they allow obesity and landscape char-

${ }^{3}$ A separate literature deals with possible causes of the trend towards higher obesity rates. While these causes are not yet well understood, several studies emphasize various aspects of technical change which have lowered the cost of calorie intake or increased the cost of calorie expenditure (including changes in the technology that allows cheaper centralized food provision) and changes in the nature of work that have made prevailing occupations more sedentary (Cutler, Glaeser, and Shapiro, 2003, Lakdawalla and Philipson, 2002, Lakdawalla, Philipson, and Bhattacharya, 2005). Longer working hours for women and declining smoking have also received attention (Anderson, Butcher, and Levine, 2003, Chou, Grossman, and Saffer, 2004).

"In addition, they are only able to control for a small set of observable characteristics that does not include, for example, any family or job-related variables. 
acteristics to be simultaneously determined by estimating a two equation model, one in which weight affects landscape and one in which landscape affects weight. They conclude that landscape has only a very small effect on weight, and that weight has a measurable effect on the choice of residential landscape. Of the extant research on this topic, Plantinga and Bernell (2005) most carefully address the issue that correlation between sprawl and obesity does not imply causation. Their study, however, has two weaknesses. First, their measure of landscape characteristics is a dichotomous county level variable derived from the sprawl index in Ewing et al. (2003) and is subject to the same problems discussed above. Second, they still do not follow individuals' changes of address and weight over time. Instead, identification of their model hinges on the assumption that marital status and family size affect weight only indirectly through their effect on landscape choice. While this assumption may be a priori defensible, our results suggest that it does not hold empirically.

In all, the existing research into the relationship between obesity and sprawl is incomplete at best. Many papers document a correlation between neighborhood characteristics and obesity. None succeeds in determining whether this correlation occurs because sprawling neighborhoods cause obesity, or because people predisposed to obesity prefer living in sprawling neighborhoods.

\section{Methodology}

The primary measure of obesity is Body Mass Index (BMI), which allows comparisons of weight holding height constant. This index is calculated by dividing an individual's weight in kilograms by his or her height in meters squared, i.e., $\mathrm{kg} / \mathrm{m}^{2} .{ }^{5}$ We will use BMI as our measure of obesity.

We want to estimate the relationship between вмI and landscape while allowing for the possibility that BмI may be explained both by an individual's observed characteristics and by his or her unobserved propensity to be obese. More formally, we would like to estimate the following model:

$$
\mathrm{BMI}_{i t}=c_{i}+\mathbf{x}_{i t} \beta+\mathbf{z}_{i t} \gamma+u_{i t} \quad t \in\{1, \ldots, T\},
$$

where $\mathrm{BMI}_{i t}$ is the BMI of individual $i$ at time $t, c_{i}$ is an unobserved time invariant effect (the individual's unobserved propensity to be obese), $\mathbf{x}_{i t}$ is a vector of observable individual characteristics, $\mathbf{z}_{i t}$ is a vector of 'landscape' variables that describe the built environment where the individual lives and $u_{i t}$ is an idiosyncratic error. ${ }^{6}$ If equation ( 1 ) is the correct representation, then existing studies suffer from a number of econometric problems.

Consider the simplest approach to examining the relationship between obesity and the built environment: a regression (possibly pooled over time) of вмI on appropriate landscape variables:

$$
\mathbf{B M I}_{i t}=\mathbf{z}_{i t} \gamma+u_{i t}
$$

A regression like (2) can tell us the correlation between landscape characteristics and obesity but does not provide consistent estimates of the effects of landscape if individual characteristics are

\footnotetext{
${ }^{5} \mathrm{~A}$ person is typically defined to be overweight if his or her BMI is between 25 and 30 , and to be obese if it is greater than 30 .

${ }^{6}$ We can also include a set of time dummies if average $\mathbf{B M I}$ is changing over time.
} 
determinants of both BмI and neighborhood. 7 The most obvious problem is that there are observable individual characteristics $\left(\mathbf{x}_{i t}\right)$ such as race and age that are likely to determine both the type of neighborhood where an individual lives and that individual's BмI. If we do not control for these omitted individual characteristics, we may detect a relationship between landscape and BMI when no effect is present.

A regression including observed individual characteristics partially helps to address this problem:

$$
\mathrm{BMI}_{i t}=\mathbf{x}_{i t} \beta+\mathbf{z}_{i t} \gamma+u_{i t} .
$$

This is the specification that is used by all existing studies, with the exception of Plantinga and Bernell (2005). However, a regression like (3) still does not generate consistent estimates of the effect of landscape on BMI if unobserved individual characteristics $\left(c_{i}\right)$ are determinants of both BMI and neighborhood. ${ }^{8}$ In particular, we might worry that an unobserved propensity to be obese may lead individuals with higher BMI to choose to live in 'sprawling' neighborhoods. To control for this, we can first-difference equation (1) with respect to time to remove the unobserved individual effect and then estimate:

$$
\Delta B M I_{i t}=\Delta \mathbf{x}_{i t} \beta+\Delta \mathbf{z}_{i t} \gamma+\Delta u_{i t} \quad t=2, \ldots, T,
$$

where $\Delta$ is the time difference operator. An alternative, which we also pursue as a robustness check, is to use the within operator to remove the unobserved individual effect.

Note that the first difference operator removes both the unobserved propensity to be obese and all other time invariant characteristics. Therefore, if we are to use this estimation strategy to identify the effect of neighborhood on вмг the data must exhibit time series variation in individuals' landscape characteristics. Built landscapes change slowly. However, people in the United States move frequently across neighborhoods and cities. While individuals have idiosyncratic preferences over neighborhood characteristics, constraints related to work, family, income and other personal circumstances mean that, when people move, the built environment in the initial and the final neighborhoods is often quite different. Provided enough individuals move and that enough moves are to different types of neighborhoods these 'movers' generate sufficient time series variation to identify the effect of neighborhood characteristics on obesity. The effect of all other time-varying variables can be identified from both movers and non-movers.

\section{Data}

To isolate the effects of neighborhood characteristics on obesity, we require a data set which:

- records an individual's height and weight so that we can calculate BмI;

- records individual characteristics that may be associated with higher BMI;

- precisely locates individuals so that we can measure the characteristics of their residential neighborhoods; and

7That is $\operatorname{plim} \hat{\gamma}=\gamma$ only if $\mathrm{E}\left(\mathbf{z}_{i t} \mid x_{i t}, c_{i}=0\right)$.

${ }^{8}$ That is plim $\hat{\gamma}=\gamma$ only if $\mathrm{E}\left(\mathbf{x}_{i t} \mid c_{i}=0\right)$ and $\mathrm{E}\left(\mathbf{z}_{i t} \mid c_{i}=0\right)$. 
- follows individuals over time so that we can control for unobserved propensities to be obese.

The National Longitudinal Survey of Youth 1979 (NLSY79) provides these data. The "crosssectional sample" of this comprehensive survey, sponsored and directed by the Bureau of Labor Statistics of the us Department of Labor, follows a nationally representative sample of 6,111 young men and women who were 14-21 years old on 31 December 1978. These individuals were interviewed annually through to 1994. The NLSY79 tracks data on the height, weight and other personal characteristics of respondents over time. ${ }^{9}$ The NLSY79 also has a Confidential Geocode portion that precisely records the latitude and longitude of each respondent's address. ${ }^{10}$

To take full advantage of the precision with which the Confidential Geocode portion of the NLSY79 reports the location of individuals' addresses, we must match it to similarly precise data measuring neighborhood characteristics. We do this by building on the methodology developed in Burchfield et al. (2006) to integrate survey, satellite, and census data.

We define each individual's neighborhood as a two-mile radius disc around the individual's residence. ${ }^{11}$ Almost any aspect of an individual's neighborhood landscape could, in theory, have an effect on weight or induce sorting on characteristics correlated with weight. The extant literature, however, has focused on two aspects in particular: first, the physical characteristics of the built environment, such as the separation between residences nearby buildings and the ease with which one can walk between them, and second, the neighborhood supply of walking destinations, like retail shops or churches. Our analysis will focus on two variables intended to measure these two aspects: residential-sprawl which measures the scatteredness of neighborhood residential development and mixed-use, which describes the neighborhood supply of retail destinations and churches. In what follows we describe the construction of these two landscape variables in turn.

Our measure of residential-sprawl is the sprawl index developed in Burchfield et al. (2006): the share of undeveloped land in the square kilometer surrounding an average residential development in the individual's neighborhood. To calculate this index, we use the 1992 land cover data from Burchfield et al. (2006). These data describe the predominant land use (e.g., residential, commercial, forest) for each of about 8.7 billion, 30 meter by 30 meter cells in a regular grid covering the continental United States. For each 30 meter by 30 meter pixel that is classified as containing residential development, we calculate the share of undeveloped land in the immediate square kilometer. We then average

\footnotetext{
9The height and weight recorded in the NLSY79 are self-reported by respondents rather than measured by interviewers. Although there is evidence that overweight individuals tend to systematically under-report their weight, the magnitude of that under-reporting is much lower for face-to-face interviews (such as those used to collect the NLSY79 data over our study period) than for telephone interviews (Ezzati et al., 2006). Nevertheless, we have re-run all our specifications using an alternative measure of вмг that uses measured and self-reported height and weight from the Third National Health and Nutrition Examination Survey (NHANES III) to correct for self-reporting bias following the same procedure as Cawley (2004). Our results remain qualitatively unchanged when we use this adjusted measure of BMI.

${ }^{10}$ The Confidential Geocode Data is available only at the Bureau of Labor Statistics National Office in Washington DC and, to our knowledge, we are the first researchers outside the BLs Columbus data center to exploit the full spatial resolution of this data. NLSY79 survey respondents are paid to participate in the survey. The latitude and longitude recorded in the Confidential Geocode Data is calculated from the mailing address to which this payment is sent. Individuals who list a post office box are assigned to the centroid of the zipcode containing this box. Personnel at the BLS estimate that only $10-15 \%$ of individuals give post office boxes rather than residences as their mailing address, though in the relevant years no formal record of this was kept (personal correspondence with Eric Fischer, 2005).

${ }^{11}$ As discussed below, our results are robust to alternative definitions of neighborhood.
} 
across all residential development in a two mile radius around the individual's address to calculate a neighborhood index of residential-sprawl.

Our measure of mixed-use is the count of retail shops (excluding auto-related) and churches in the individual's neighborhood (in thousands). We calculate this based on establishment counts from the 1994 Zipcode Business Patterns data set of the us Census Bureau. To compute how many stores and churches are in a two mile radius around the individual's address, we allocate establishments in each zipcode equi-proportionately to all 30 meter by 30 meter cells within the zipcode that are classified as built-up in the 1992 land-use data. Note that our neighborhood mixed-use variable is not based on the count of all establishments within a two mile radius. Instead, in order to be consistent with the extant literature, mixed-use records only nearby retail shops and churches. ${ }^{12}$

The combination of these three data sets allows us to examine the relationship between вмI and landscape much more carefully than has previously been possible. Unlike any extant data we record a panel of individual BMI observations and an extensive description of each individual at each time. We also have accurate landscape measures observed at a very fine spatial scale, and benefit from the landscape variation afforded by the entire continental us.

We use data from six waves of the cross-sectional sample of the NLSY79: 1988-1990 and 19921994. We cannot use data from 1991 because the NLSY79 did not ask people for their weight in that year. We focus on this study period for two reasons. First, because the study period brackets our 1992 landcover data. Second, because 1994 marks the year when the NLSY79 switched to bi-annual surveys.

There are 2,862 men and 2,997 women who are interviewed at least once in the six waves of the NLSY79 that we consider. For an individual to be included in the basic sample, we must have height, weight and location data for at least two years. ${ }^{13}$ Imposing this restriction gives us a panel of 2,780 men and 2,881 women. Detailed inspection of the data shows that 26 men and 41 women record changes in BMI of magnitudes greater than 10 over a single year. Such huge changes are implausible and appear to be the result of coding errors, ${ }^{14}$ so we drop these individuals. We always know the race and age of respondents, so we are able to include those individual characteristics without further restricting the sample. Including additional individual characteristics causes us to drop a further 155 men and 127 women. Table 4 in Appendix A provides summary statistics for the full and restricted sub-samples. In the text, we always report results for the most restricted sample of individuals to ensure that changes in estimated coefficients across specifications are not driven

\footnotetext{
${ }^{12}$ More precisely, mixed-use counts neighborhood establishments in the following standard industrial classifications: building materials and garden supplies stores, general merchandise stores, food stores, apparel and accessory stores, furniture and home furnishings stores, drug stores and proprietary stores, liquor stores, used merchandise stores, miscellaneous shopping goods stores, retail stores not otherwise classified (e.g., florists, tobacco stores, newsstands, optical goods stores), and religious organizations. Note that we include grocery stores, but exclude bars and restaurants. This is consistent with the finding in the literature that a greater presence of grocery stores near an individual's address is correlated with greater consumption of fresh fruits and vegetables but that a greater presence of fast-food restaurants is correlated with larger weight. We have experimented with variants of mixed-use that include bars and restaurants or exclude grocery stores and found no qualitative changes in our results.

${ }^{13}$ We do not have neighborhood data for Hawaii or Alaska, so individuals must actually live in the conterminous us for at least two years.

${ }^{14}$ They typically involve someone who records very similar values of weight throughout our study period except in a single year when their recorded weight jumps up or down, often by almost exactly 100 pounds, to then return to the usual value.
} 
by changes to the underlying sample. Tables 5 and 6 in Appendix A report the same specifications using the largest possible samples. The results reported there show that our conclusions are not driven by the sample restrictions that we impose.

\section{Results}

We begin by pooling the data over all years and estimating equation (2) to give the correlation between вмг and our measures of residential-sprawl and mixed-use. We include a set of year dummies in this and all other specifications to allow for the fact that average BMI increases over time. We estimate separate regressions for men and women. This is motivated by the fact that not only is the average incidence of obesity much higher in women than in men, but that there are often large differences between the obesity rates of men and women in a given location relative to the national average. For instance, DC's $21 \%$ obesity rate for men is the second lowest in the country while its $37 \%$ obesity rate for women is (tied with four other states) the highest in the country (Ezzati et al., 2006).

Results for men and women are reported in the first column (OLS1) of tables 1 and 2, respectively. For men, consistent with the existing literature, there is a positive correlation between BMI and residential-sprawl and a negative correlation between BмI and mixed-use (although, without any controls, only the latter is statistically significant). For women, we find no evidence of significant correlation between obesity and either of the landscape variables. This confirms our prior that dealing with men and women separately is important. In light of this, it is surprising that none of the studies discussed in the literature review present results separated by sex.

For our second specification we estimate equation (3) with race dummies and a quadratic for age (since weight typically first increases and then decreases with age) as individual control variables. For men, we find (oLs2 in table 1) that the correlation between obesity and both landscape variables is statistically significant and larger in absolute value once we control for age, age squared and race. We can give some idea of the magnitude of the coefficients from the sample means and standard deviations of the variables reported in the third column (FD) of Table 4 in Appendix A. An average man of 1.79 meters ( 5 feet and ten inches) who lives in a 'sprawling' neighborhood one standard deviation above the mean weighs $0.82 \mathrm{~kg}$ (1.81 pounds) more than an average individual who lives in a 'compact' neighborhood one standard deviation below the mean. ${ }^{15}$ For mixed-use the difference in mean weights is almost twice as much at $1.34 \mathrm{~kg}$. Looking at the coefficients on the two race dummies in table $I$ it is easy to understand why controlling for race is important. Black men have a BMI that is, on average, 0.704 higher than white men with the same age and neighborhood characteristics, while hispanics have a BMI that is 1.691 higher. As both blacks and hispanics are more likely to live downtown (typically areas with low residential-sprawl and high mixed-use) these differences in average BмI work against the correlation with the landscape variables. The differences in average weight are even more marked for black and hispanic women relative to white women. The results (OLS2 in table 2) show that, for given age and neighborhood

\footnotetext{
${ }^{15}$ The difference in вмг is 0.256 (equals two times the standard deviation of the sprawl variable, 0.281 , times the coefficient on sprawl, 0.455). To go from вмI to kilograms one then multiplies by 3.2041 (the average height, 1.79, squared).
} 
Table 1. BMI on residential-sprawl, mixed-use and individual characteristics (Men)

\begin{tabular}{|c|c|c|c|c|}
\hline Variable & [OLS1] & [OLS2] & [oLs3] & [FD] \\
\hline Residential-sprawl & $\begin{array}{l}0.294 \\
(0.258)\end{array}$ & $\begin{array}{l}0.455 \\
(0.259)^{*}\end{array}$ & $\begin{array}{c}-0.162 \\
(0.267)\end{array}$ & $\begin{array}{c}-0.042 \\
(0.119)\end{array}$ \\
\hline Mixed-use & $\begin{array}{l}-3.047 \\
(1.080)^{* * *}\end{array}$ & $\begin{array}{l}-3.950 \\
(1.073)^{* * *}\end{array}$ & $\begin{array}{c}-2.814 \\
(1.072)^{* * *}\end{array}$ & $\begin{array}{l}0.497 \\
(0.663)\end{array}$ \\
\hline Age & & $\begin{array}{c}0.896 \\
(0.209)^{* * *}\end{array}$ & $\begin{array}{c}0.863 \\
(0.229)^{* * *}\end{array}$ & $\begin{array}{l}0.585 \\
(0.144)^{* * *}\end{array}$ \\
\hline $\mathrm{Age}^{2}$ & & $\begin{array}{l}-0.013 \\
(0.003)^{* * *}\end{array}$ & $\begin{array}{l}-0.012 \\
(0.004)^{* * *}\end{array}$ & $\begin{array}{l}-0.006 \\
(0.002)^{* * *}\end{array}$ \\
\hline Black & & $\begin{array}{c}0.704 \\
(0.230)^{* * *}\end{array}$ & $\begin{array}{c}0.679 \\
(0.242)^{* * *}\end{array}$ & \\
\hline Hispanic & & $\begin{array}{c}1.691 \\
(0.367)^{* * *}\end{array}$ & $\begin{array}{c}1.266 \\
(0.362)^{* * *}\end{array}$ & \\
\hline Years schooling & & & $\begin{array}{c}-0.155 \\
(0.040)^{* * *}\end{array}$ & $\begin{array}{l}0.081 \\
(0.054)\end{array}$ \\
\hline Daily smoker & & & $\begin{array}{c}-1.008 \\
(0.170)^{* * *}\end{array}$ & $\begin{array}{c}-0.119 \\
(0.185)\end{array}$ \\
\hline Married & & & $\begin{array}{l}0.183 \\
(0.181)\end{array}$ & $\begin{array}{l}0.322 \\
(0.064)^{* * *}\end{array}$ \\
\hline Working spouse & & & $\begin{array}{l}0.271 \\
(0.146)^{*}\end{array}$ & $\begin{array}{c}-0.030 \\
(0.037)\end{array}$ \\
\hline Children in household & & & $\begin{array}{l}0.109 \\
(0.083)\end{array}$ & $\begin{array}{l}0.009 \\
(0.037)\end{array}$ \\
\hline Newborn & & & $\begin{array}{c}-0.142 \\
(0.129)\end{array}$ & $\begin{array}{l}0.070 \\
(0.045)\end{array}$ \\
\hline In work & & & $\begin{array}{l}-0.336 \\
(0.162)^{* *}\end{array}$ & $\begin{array}{l}-0.139 \\
(0.053)^{* * *}\end{array}$ \\
\hline Annual hours worked $(1,000)$ & & & $\begin{array}{c}0.225 \\
(0.084)^{* * *}\end{array}$ & $\begin{array}{l}-0.056 \\
(0.030)^{*}\end{array}$ \\
\hline Annual earnings $(\$ 1,000)$ & & & $\begin{array}{c}-0.003 \\
(0.004)\end{array}$ & $\begin{array}{l}0.001 \\
(0.001)\end{array}$ \\
\hline Job strength & & & $\frac{1.110}{(0.288)^{* * *}}$ & $\begin{array}{c}-0.168 \\
(0.309)\end{array}$ \\
\hline Job strenuousness & & & $\begin{array}{l}-0.706 \\
(0.276)^{* *}\end{array}$ & $\begin{array}{l}0.052 \\
(0.292)\end{array}$ \\
\hline Observations & 14446 & 14446 & 13128 & 10445 \\
\hline Individuals & 2527 & 2527 & 2527 & 2527 \\
\hline$R^{2}$ & 0.02 & 0.04 & 0.07 & 0.05 \\
\hline
\end{tabular}

Notes: The dependent variable is BMI. OLS1, OLS2, and OLS3 are estimated pooling data over all years, while FD is estimated in first differences. Year dummies are included in all specifications. Numbers in parenthesis report clustered standard errors. ${ }^{* *},{ }^{* *}$, and ${ }^{*}$ indicate significance at the $1 \%, 5 \%$ and $10 \%$ level, respectively. 
Table 2. вмI on residential-sprawl, mixed-use and individual characteristics (Women)

\begin{tabular}{|c|c|c|c|c|}
\hline Variable & [OLSI] & [OLS2] & [OLS3] & [FD] \\
\hline Residential-sprawl & $\begin{array}{l}0.016 \\
(0.360)\end{array}$ & $\begin{array}{l}0.539 \\
(0.341)\end{array}$ & $\begin{array}{c}-0.118 \\
(0.346)\end{array}$ & $\begin{array}{c}-0.154 \\
(0.135)\end{array}$ \\
\hline Mixed-use & $\begin{array}{l}0.623 \\
(2.236)\end{array}$ & $\begin{array}{c}-2.249 \\
(1.801)\end{array}$ & $\begin{array}{c}-0.735 \\
(1.777)\end{array}$ & $\begin{array}{c}-0.473 \\
(0.640)\end{array}$ \\
\hline Age & & $\begin{array}{l}0.531 \\
(0.269)^{* *}\end{array}$ & $\begin{array}{c}0.809 \\
(0.288)^{* * *}\end{array}$ & $\begin{array}{c}0.527 \\
(0.186)^{* * *}\end{array}$ \\
\hline $\mathrm{Age}^{2}$ & & $\begin{array}{c}-0.007 \\
(0.005)\end{array}$ & $\begin{array}{l}-0.011 \\
(0.005)^{* *}\end{array}$ & $\begin{array}{l}-0.005 \\
(0.003)^{*}\end{array}$ \\
\hline Black & & $\begin{array}{c}3.605 \\
(0.342)^{* * *}\end{array}$ & $\begin{array}{l}2.948 \\
(0.357)^{* * *}\end{array}$ & \\
\hline Hispanic & & $\begin{array}{c}1.758 \\
(0.425)^{* * *}\end{array}$ & $\begin{array}{c}1.339 \\
(0.433)^{* * *}\end{array}$ & \\
\hline Years schooling & & & $\begin{array}{l}-0.254 \\
(0.048)^{* * *}\end{array}$ & $\begin{array}{l}0.024 \\
(0.059)\end{array}$ \\
\hline Daily smoker & & & $\begin{array}{c}-0.849 \\
(0.208)^{* * *}\end{array}$ & $\begin{array}{c}-0.301 \\
(0.224)\end{array}$ \\
\hline Married & & & $\begin{array}{l}0.036 \\
(0.299)\end{array}$ & $\begin{array}{c}0.435 \\
(0.097)^{* * *}\end{array}$ \\
\hline Working spouse & & & $\begin{array}{c}-0.114 \\
(0.238)\end{array}$ & $\begin{array}{l}0.077 \\
(0.068)\end{array}$ \\
\hline Children in household & & & $\begin{array}{c}-0.023 \\
(0.098)\end{array}$ & $\begin{array}{l}0.054 \\
(0.061)\end{array}$ \\
\hline Newborn & & & $\begin{array}{c}0.527 \\
(0.157)^{* * *}\end{array}$ & $\begin{array}{c}0.592 \\
(0.064)^{* * * *}\end{array}$ \\
\hline Pregnant & & & $\begin{array}{c}1.828 \\
(0.197)^{* * *}\end{array}$ & $\begin{array}{l}1.882 \\
(0.096)^{* * *}\end{array}$ \\
\hline In work & & & $\begin{array}{c}-0.067 \\
(0.153)\end{array}$ & $\begin{array}{l}-0.170 \\
(0.053)^{* * *}\end{array}$ \\
\hline Annual hours worked $(1,000)$ & & & $\begin{array}{c}0.368 \\
(0.097)^{* * *}\end{array}$ & $\begin{array}{c}-0.047 \\
(0.032)\end{array}$ \\
\hline Annual earnings $(\$ 1,000)$ & & & $\begin{array}{l}-0.030 \\
(0.008)^{* * *}\end{array}$ & $\begin{array}{c}-0.003 \\
(0.002)\end{array}$ \\
\hline Job strength & & & $\begin{array}{c}0.696 \\
(0.289)^{* *}\end{array}$ & $\begin{array}{c}-0.491 \\
(0.315)\end{array}$ \\
\hline Job strenuousness & & & $\begin{array}{l}0.752 \\
(0.406)^{*}\end{array}$ & $\begin{array}{l}0.343 \\
(0.320)\end{array}$ \\
\hline Observations & 15156 & 15156 & 14077 & 11240 \\
\hline Individuals & 2663 & 2663 & 2663 & 2663 \\
\hline$R^{2}$ & 0.01 & 0.06 & 0.10 & 0.11 \\
\hline
\end{tabular}

Notes: The dependent variable is BMI. OLS1, OLS2, and OLS3 are estimated pooling data over all years, while FD is estimated in first differences. Year dummies are included in all specifications. Numbers in parenthesis report clustered standard errors. ${ }^{* *},{ }^{* *}$, and ${ }^{*}$ indicate significance at the $1 \%, 5 \%$ and $10 \%$ level, respectively. 
characteristics, BмI is 3.605 higher for black women and 1.758 higher for hispanic women. Thus, unsurprisingly, controlling for race has a large impact on the point estimates of the landscape variables for women. In the specifications that we report in the text, these correlations are not quite significant at the $10 \%$ level. In other specifications, for example those reported in table 6, small changes to the sample give slightly different coefficients and standard errors, and push the correlation between obesity and residential-sprawl marginally past the $10 \%$ significance threshold.

For our third specification we again estimate equation (3) but now with a larger set of controls. The third column (oLs3) of tables 1 and 2 reports these results. Before considering the impact on the coefficients of the two landscape variables we briefly comment on the effect of each of the individual characteristics. For both men and women, tables 1 and 2 show that individuals with more years of schooling or who smoke daily have a statistically significantly lower BMI. There are no statistically significant differences in BMI between individuals (men or women) who are married and those who are not. For married men, however, there is a statistically significant positive relationship between having a working spouse and BMI. Men with more children in their household or who have a newborn child (under 12 months) do not exhibit statistically significant differences in their BмI from those who do not. For women, while the number of children per se does not appear to make a difference, those who are pregnant or who have had a child within the previous twelve months do have a statistically significant higher BMI. Moving on to work-related variables, men who work tend to weigh less than those who do not, while women who work are no different in terms of their weight. Conditional on working, working longer hours is positively related to BмI for both men and women. Women with higher total earnings weigh less, but total earnings make no difference for men once we have controlled for education. Two measures of job-related exercise previously used by Lakdawalla and Philipson (2002) also have significant effects on BMI. Both are constructed on the basis of each worker's 3-digit occupational category. 'Strength' is a rating of the strength required to perform a job and is meant to capture muscle mass that will result in a higher BMI. 'Strenuousness' rates other physical demands (including climbing, reaching, stooping, and kneeling). As expected, both men and women with jobs that require more strength tend to weigh more. Job strenuousness tends to decrease men's weight but to increase women's.

Turning now to the effect on the landscape variables, for men, we see that the positive correlation between residential-sprawl and BмI does not persist after introducing these additional controls. This tells us that these observable characteristics explain both the propensity to be obese and the tendency to live in a sprawling neighborhood. We do, however, continue to find a negative correlation between mixed-use and BмI for men. For women neither residential-sprawl nor mixed-use are even close to being significant once we include the full set of controls. Of course, before attaching any causal interpretation to the negative correlation between mixed-use and BмI for men, we would still like to take account of unobserved individual heterogeneity and it is to this that turn next.

The fourth columns (FD) of tables 1 and 2 show what happens when we use the panel dimension of our data to control for unobserved individual effects by first differencing and estimating equation (4). As a reminder, we take advantage of the fact that $79 \%$ of our sample moves at least once 
over the study period to see whether a given individual, with some unobserved propensity to be obese, changes their weight when they move to a different type of neighborhood. The specification includes a full set of individual controls $\left(x_{i t}\right)$ as well as appropriate year dummies. ${ }^{16}$ We see that once we control for unobserved individual characteristics there is no relationship between BMI and either residential-sprawl or mixed-use. ${ }^{17}$ This suggests that the negative significant relationship between BмI and mixed-use that we found for men reflects sorting of men with an unobserved propensity to be less obese into neighborhoods which are mixed-use. Note that several of the individual controls are significant in this specification: changes in marital status, employment status, or working hours affect a given person's weight. To summarize, we find that there is no relationship between BMI and neighborhood characteristics once we control for both observed and unobserved individual effects.

\section{Robustness}

This subsection checks the robustness of our results. We first consider problems relating specifically to our methodology before turning to more generic issues of functional form and neighborhood variable definitions.

One possible problem with our approach is that individuals may receive a time-varying shock to their unobserved propensity to be obese that causes them to move and which prevents us from picking up the true relationship between residential-sprawl or mixed-use and BMI using our first difference specification. That is, there is correlation between the time varying idiosyncratic error $\left(u_{i t}\right)$ and the explanatory variables $\left(\mathbf{x}_{i t}, \mathbf{z}_{i t}\right)$. Two pieces of evidence argue against this possibility. First, the Wald test proposed by Wooldridge (2002, p. 285), fails to reject the exogeneity assumption necessary for the consistency of our first difference estimator. According to this test we cannot reject the null hypothesis that the idiosyncratic error is uncorrelated with the explanatory variables. Second, the pattern of correlations needed for this to explain our results is very particular and highly counter-intuitive. Specifically, assume that there is truly a negative relationship between mixed-use and BMI. To explain our finding of no effect after conditioning out time invariant unobserved propensity to be obese we must assume that individuals who experience an unobserved increase in their propensity to be obese move to neighborhoods with more mixed-use. However, we have already seen that time-invariant unobserved propensity to be obese causes individuals to sort to neighborhoods with less mixed-use. That is, we would need the sorting on time-varying unobserved propensity to work in the opposite direction to the sorting on time-invariant unobserved propensity. This seems very unlikely. ${ }^{18}$

\footnotetext{
${ }^{16}$ Note that our first difference regressions include both a full set of year dummies and age. The fact that NLsY79 respondents are interviewed on different dates each year means that $\Delta$ age is not equal to one for all individuals and there is sufficient variation in the data to identify both the year dummies and age.

${ }^{17}$ If we use the within operator to remove the unobserved individual effect as an alternative to this first-difference specification, we reach exactly the same conclusions.

${ }^{18}$ Technically, the restriction is that the sign of the partial correlation between BMI and time-invariant propensity to be obese would need to be the opposite of the sign of the partial correlation between BMI and the time-varying unobserved propensity to be obese. This still seems highly unlikely.
} 
Our identification of the effect of neighborhood on BмI comes from looking what happens to people when they move. This raises three concerns. First, movers may tend to move between similar neighborhoods so there is very little time series variation from which to estimate the effect of neighborhoods. Second, it may take time before neighborhood affects weight. Third, moving may be associated with life-cycle events that make it hard to identify an effect on BMI. Table 3 presents three sets of regressions (for men and women) that address these concerns.

To address the first concern, that moves tend to be between similar neighborhoods implying little time series variation in neighborhood characteristics, we can consider a subsample consisting only of movers who experience large changes in neighborhood characteristics. Specifically, we first calculate the magnitude of the change in our residential-sprawl index that would be required to move an individual from the top of the bottom third of the sample, to the bottom of the top third of the sample. We define this magnitude to be a 'large' change in the residential-sprawl index. We proceed similarly for mixed-use. We then restrict attention to movers who experience at least this large a change in their neighborhood residential-sprawl index or their neighborhood mixed-use index over the course of the sample. Column R1 in table 3 shows that even when we restrict the sample to individuals that experience large moves we cannot detect any effect of neighborhood on BMI after controlling for unobserved individual effects: a lack of time series variation in neighborhood characteristics for individuals does not explain our results.

Next, we consider the possibility that it takes several years for changes in neighborhood to affect weight. To do this, we construct long differences for a sample of individuals who only move once during the study period. Specifically, we restrict the sample of movers to individuals who only move once and only move in either 1990 or 1992. The dependent variable is now the 'long difference' of вмI. That is, the change in вмI between the first and last year for which we observe data for each individual mover. Changes in individual characteristics are calculated similarly. ${ }^{19}$ As these individuals move in either 1990 or 1992 this gives us between two and four years to observe the effect of neighborhood for those individuals. Specification R2 in table 3 shows that even if we allow longer for changes in neighborhood to affect weight we cannot detect any effect of residential-sprawl on BMI after controlling for unobserved individual effects. In fact, for men, higher mixed-use is associated with a statistically significant increase in BMI when we allow more time for neighborhood to have an effect on weight. This is the only case in which we find a statistically significant coefficient on one of the neighborhood variables in our first-difference specifications and it runs contrary to what the literature has claimed so far: men in this particular sub-sample who move to a neighborhood with more shops and churches tend to see their weight increase.

Finally, we consider whether major lifestyle changes that occur at the same time as moves are preventing us from properly identifying the effect of neighborhood. Of course, we are already controlling for observable changes in lifestyle so for this to be an issue it must be that major lifestyle changes are associated with both moving and changes to unobservable characteristics with the

\footnotetext{
${ }^{19}$ For most movers, this involves differencing over the whole study period. For a small number of individuals with missing data, we difference over smaller time periods. The set of time dummies is constructed to allow for the fact that differencing may be over slightly different time periods.
} 
Table 3. вмI on residential-sprawl, mixed-use and individual characteristics (sub-samples)

\begin{tabular}{|c|c|c|c|c|c|c|}
\hline \multirow[b]{2}{*}{ Variable } & \multicolumn{3}{|c|}{ Men } & \multicolumn{3}{|c|}{ Women } \\
\hline & [RI] & [R2] & [R3] & [RI] & [R2] & [R3] \\
\hline Residential-sprawl & $\begin{array}{c}-0.044 \\
(0.135)\end{array}$ & $\begin{array}{l}0.186 \\
(0.382)\end{array}$ & $\begin{array}{l}0.171 \\
(0.217)\end{array}$ & $\begin{array}{c}-0.114 \\
(0.146)\end{array}$ & $\begin{array}{c}-0.284 \\
(0.414)\end{array}$ & $\begin{array}{c}-0.191 \\
(0.236)\end{array}$ \\
\hline Mixed-use & $\begin{array}{l}0.567 \\
(0.687)\end{array}$ & $\begin{array}{l}2.970 \\
(1.643)^{*}\end{array}$ & $\begin{array}{l}0.866 \\
(0.922)\end{array}$ & $\begin{array}{c}-0.424 \\
(0.632)\end{array}$ & $\begin{array}{c}-0.175 \\
(1.533)\end{array}$ & $\begin{array}{c}-0.263 \\
(0.809)\end{array}$ \\
\hline Age & $\begin{array}{c}0.538 \\
(0.192)^{* * *}\end{array}$ & $\begin{array}{l}0.726 \\
(0.571)\end{array}$ & $\begin{array}{c}0.572 \\
(0.250)^{* *}\end{array}$ & $\begin{array}{l}0.487 \\
(0.232)^{* *}\end{array}$ & $\begin{array}{l}-1.159 \\
(0.669)^{*}\end{array}$ & $\begin{array}{l}0.368 \\
(0.294)\end{array}$ \\
\hline $\mathrm{Age}^{2}$ & $\begin{array}{c}-0.004 \\
(0.003)\end{array}$ & $\begin{array}{l}-0.006 \\
(0.003)^{* *}\end{array}$ & $\begin{array}{l}-0.006 \\
(0.004)^{*}\end{array}$ & $\begin{array}{c}-0.004 \\
(0.003)\end{array}$ & $\begin{array}{c}-0.004 \\
(0.003)\end{array}$ & $\begin{array}{c}-0.003 \\
(0.004)\end{array}$ \\
\hline Years schooling & $\begin{array}{l}0.122 \\
(0.066)^{*}\end{array}$ & $\begin{array}{c}-0.098 \\
(0.132)\end{array}$ & $\begin{array}{l}0.102 \\
(0.080)\end{array}$ & $\begin{array}{l}0.040 \\
(0.068)\end{array}$ & $\begin{array}{l}0.145 \\
(0.109)\end{array}$ & $\begin{array}{l}0.107 \\
(0.082)\end{array}$ \\
\hline Daily smoker & $\begin{array}{c}-0.216 \\
(0.244)\end{array}$ & $\begin{array}{l}-0.877 \\
(0.438)^{* *}\end{array}$ & $\begin{array}{l}0.133 \\
(0.253)\end{array}$ & $\begin{array}{c}-0.188 \\
(0.270)\end{array}$ & $\begin{array}{c}-0.530 \\
(0.488)\end{array}$ & $\begin{array}{c}-0.272 \\
(0.403)\end{array}$ \\
\hline Married & $\begin{array}{c}0.261 \\
(0.080)^{* * *}\end{array}$ & $\begin{array}{l}0.308 \\
(0.233)\end{array}$ & & $\begin{array}{l}0.448 \\
(0.121)^{* * * *}\end{array}$ & $\begin{array}{l}0.575 \\
(0.324)^{*}\end{array}$ & \\
\hline Working spouse & $\begin{array}{l}0.017 \\
(0.047)\end{array}$ & $\begin{array}{c}-0.204 \\
(0.192)\end{array}$ & $\begin{array}{l}-0.196 \\
(0.088)^{* *}\end{array}$ & $\begin{array}{l}0.077 \\
(0.084)\end{array}$ & $\begin{array}{r}-0.127 \\
(0.286)\end{array}$ & $\begin{array}{r}-0.047 \\
(0.126)\end{array}$ \\
\hline Children in household & $\begin{array}{c}-0.030 \\
(0.046)\end{array}$ & $\begin{array}{l}-0.183 \\
(0.091)^{* *}\end{array}$ & & $\begin{array}{l}0.070 \\
(0.073)\end{array}$ & $\begin{array}{l}0.060 \\
(0.117)\end{array}$ & \\
\hline Newborn & $\begin{array}{l}0.052 \\
(0.060)\end{array}$ & $\begin{array}{l}0.036 \\
(0.193)\end{array}$ & & $\begin{array}{l}0.544 \\
(0.081)^{* * *}\end{array}$ & $\begin{array}{c}0.778 \\
(0.205)^{* * *}\end{array}$ & \\
\hline Pregnant & & & & $\begin{array}{c}1.806 \\
(0.120)^{* * *}\end{array}$ & $\begin{array}{c}1.782 \\
(0.360)^{* * *}\end{array}$ & \\
\hline In work & $\begin{array}{l}-0.192 \\
(0.063)^{* * *}\end{array}$ & $\begin{array}{c}-0.183 \\
(0.255)\end{array}$ & $\begin{array}{l}-0.138 \\
(0.077)^{*}\end{array}$ & $\begin{array}{l}-0.143 \\
(0.066)^{* *}\end{array}$ & $\begin{array}{c}-0.278 \\
(0.171)\end{array}$ & $\begin{array}{c}-0.053 \\
(0.088)\end{array}$ \\
\hline Annual hours worked $(1,000)$ & $\begin{array}{c}-0.050 \\
(0.037)\end{array}$ & $\begin{array}{c}-0.135 \\
(0.094)\end{array}$ & $\begin{array}{c}-0.030 \\
(0.053)\end{array}$ & $\begin{array}{c}-0.037 \\
(0.039)\end{array}$ & $\begin{array}{l}0.116 \\
(0.104)\end{array}$ & $\begin{array}{c}-0.070 \\
(0.053)\end{array}$ \\
\hline Annual earnings $(\$ 1,000)$ & $\begin{array}{l}0.000 \\
(0.002)\end{array}$ & $\begin{array}{l}0.002 \\
(0.005)\end{array}$ & $\begin{array}{c}-0.001 \\
(0.002)\end{array}$ & $\begin{array}{c}-0.003 \\
(0.002)\end{array}$ & $\begin{array}{c}-0.011 \\
(0.009)\end{array}$ & $\begin{array}{l}-0.008 \\
(0.003)^{* *}\end{array}$ \\
\hline Job strength & $\begin{array}{l}-0.560 \\
(0.365)\end{array}$ & $\begin{array}{l}0.912 \\
(0.563)\end{array}$ & $\begin{array}{l}0.593 \\
(0.470)\end{array}$ & $\begin{array}{c}-0.333 \\
(0.380)\end{array}$ & $\begin{array}{l}0.063 \\
(0.503)\end{array}$ & $\begin{array}{c}-0.625 \\
(0.477)\end{array}$ \\
\hline Strenuous & $\begin{array}{l}0.372 \\
(0.349)\end{array}$ & $\begin{array}{l}-0.960 \\
(0.549)^{*}\end{array}$ & $\begin{array}{c}-0.595 \\
(0.481)\end{array}$ & $\begin{array}{l}0.235 \\
(0.384)\end{array}$ & $\begin{array}{c}-0.442 \\
(0.510)\end{array}$ & $\begin{array}{l}0.442 \\
(0.529)\end{array}$ \\
\hline Observations & 7033 & 742 & 3883 & 7434 & 1029 & 3806 \\
\hline Individuals & 1713 & 742 & 945 & 1774 & 1029 & 919 \\
\hline$R^{2}$ & 0.05 & 0.34 & 0.05 & 0.11 & 0.28 & 0.05 \\
\hline
\end{tabular}

Notes: The dependent variable is BMI. Regression results in first differences for restricted sub-samples. RI restricts the sample of movers to individuals who experience large changes in their neighborhood characteristics. R2 restricts the sample of movers to individuals who only move once and in either 1990 or 1992 and uses long-differences. R3 restricts the sample of movers to individuals who do not experience a change in marital status or child-related variables. We continue to use the full set of non-movers to help identify the coefficients on individual characteristics. Year dummies are included in all specifications. Numbers in parenthesis report clustered standard errors. ${ }^{* * *},{ }^{* *}$, and ${ }^{*}$ indicate significance at the $1 \%, 5 \%$ and $10 \%$ level, respectively. 
effect of the latter dominating the effect of the former. To check whether this could be driving our findings we identify two major lifestyle changes, getting married and starting a family, and exclude all movers who experience such lifestyle changes during the study period. ${ }^{20}$ We also exclude women who become pregnant. Once again, results reported in column R3 of table 3 show no effect of residential-sprawl or mixed-use for men or women.

To summarize, focusing only on large moves, allowing for a time delay for the effects to occur and looking only at individuals who experience no major life cycle changes does not change or conclusion that there is no causal relationship between neighborhood and BMI.

We briefly consider three further concerns, not specific to our methodology. The first is that the relationship between the landscape variables and BMI may be non-linear. We find that parametric specifications including a quadratic term and semi-parametric specifications allowing for arbitrary non-linearity both show no evidence of a non-linear relationship between BMI and landscape characteristics.

The second concern is that relative to a number of existing studies we have not only changed the method of estimation to control for unobserved propensity to be obese, but also the scale and the definition of the neighborhood variables. To address this concern, we bring our analysis as close as possible to that of Ewing et al. (2003), while maintaining our method of estimation. First, we re-estimate our specifications at the county level (the scale of the Ewing et al., 2003, analysis). Our results (not reported) remain qualitatively unchanged for all the specifications reported in tables 1 and 2. We then go one step further by re-estimating our specifications at the county level and measuring sprawl using the same Smart Growth America index as Ewing et al. (2003). Results (reported in Appendix B) show that we still reach the same conclusions about the effect of sprawl on BмI: there is no evidence of a causal relationship between neighborhood and weight. That is, the crucial difference that drives our findings is that we control for unobserved propensity to be obese when estimating the effect of neighborhood on BMI.

A final concern relates to the possibility that our first-difference specification may only capture the "effect of treatment on the treated" (Heckman and Robb, 1985). That is, suppose some people gain weight when they move to a more sprawling neighborhood and others do not. If those who would experience an effect on their weight avoid moving because they do not wish to become obese, we may fail to observe any movers to more sprawling neighborhoods gaining weight even if for some (those that do not move) there would be an effect. However, an advantage of the issue we are studying is that we observe people moving to less sprawling neighborhoods as well as to more sprawling neighborhoods. Thus, the flip-side of the above argument is that, just as those who would experience a large effect on their weight from a neighborhood change will tend to self-select out of the more sprawling neighborhood "treatment" (biasing the coefficients downwards), they will tend to self-select into the less sprawling neighborhood "treatment" (biasing the coefficients upwards). If these issues are important, we should see a much larger effect of moves to neighborhoods with lower residential-sprawl and higher mixed-use than of moves to neighborhoods with higher residential-sprawl and lower mixed-use. In fact, when we allow the effects of increases

\footnotetext{
${ }^{20}$ Specifically, we drop individuals who change marital status or who experience a change in the number of children in the household.
} 
and decreases in our neighborhood variables to be different, we find no evidence of statistically significant differences. Thus, we conclude that the possibility that people may be more or less likely to move depending on how moving will affect their weight does not drive our results.

\section{Conclusion}

It has been widely observed that urban sprawl is associated with higher rates of obesity. This observation has led many researchers to infer that urban sprawl causes obesity. The available evidence does not, in fact, permit this conclusion. The higher observed rates of obesity associated with urban sprawl are also consistent with the sorting of obese people into sprawling neighborhoods.

In this paper we conduct an analysis which permits us to distinguish between these two possibilities. Our results strongly suggest that urban sprawl does not cause weight gain. Rather, people who are more likely to be obese (e.g., because they have an idiosyncratic distaste for walking) are also more likely to move to sprawling neighborhoods (e.g., because they can more easily move around by car). Of course the built environment may still place constraints on the type of exercise that people are able to take or the nature of the diet that they consume. The key point is that individuals who have a lower propensity to being obese will choose to avoid those kinds of neighborhoods. What if they are not always able to avoid those neighborhoods because (say) their choice is constrained for financial reasons? Our results suggest that, even then, individuals adjust their exercise and diet to avoid gaining weight. Overall, we find no evidence that neighborhood characteristics have any causal effect on weight.

We recognize that the debate over urban sprawl and obesity is ideologically charged, and that by contradicting the received literature on sprawl and obesity our conclusions will be controversial and (in some circles) unpopular. However, while our findings contradict the received literature on sprawl and obesity, they are broadly consistent with other research on neighborhood effects and the importance of sorting. For example, Combes, Duranton, and Gobillon (2004) find that much of the cross-sectional differences in wage rates across cities may be attributed to the sorting of high and low wage individuals rather than to intrinsic city level differences in productivity. Similarly, Bayer and McMillan (2005) argue that sorting into racially homogenous neighborhoods is important enough that most people are willing to pay a premium for such neighborhoods. Durlauf's (2004) recent survey includes further examples and discussion of the difficulties that sorting presents for the empirical literature that considers the effects of neighborhood on socioeconomic outcomes. Thus, our results are consistent with other findings that sorting rather than causation is the mechanism which drives observed differences in individual characteristics across places.

It follows immediately from our results that recent calls to redesign cities in order to combat the rise in obesity are misguided. Our results do not provide a basis for thinking that such redesigns

will have the desired effect, and therefore suggest that resources devoted to this cause will be wasted. The public health battle against obesity is better fought on other fronts. 


\section{References}

American Obesity Association. 2002. Health effects of obesity. Fact sheet, American Obesity Association. http://www .obesity.org/subs/fastfacts/Health_Effects.shtml.

Anderson, Patricia M., Kristin F. Butcher, and Phillip B. Levine. 2003. Maternal employment and overweight children. Journal of Health Economics 22(3):477-504.

Bayer, Patrick and Robert McMillan. 2005. Racial sorting and neighborhood quality. Working Paper 11813, National Bureau of Economic Research.

Burchfield, Marcy, Henry G. Overman, Diego Puga, and Matthew A. Turner. 2006. Causes of sprawl: A portrait from space. Quarterly Journal of Economics 121(2):587-633.

Cawley, John. 2004. The impact of obesity on wages. Journal of Human Resources 39(2):451-474.

Chou, Shin-Yi, Michael Grossman, and Henry Saffer. 2004. An economic analysis of adult obesity: results from the Behavioral Risk Factor Surveillance System. Journal of Health Economics 23(3):565-587.

Combes, Pierre-Philippe, Gilles Duranton, and Laurent Gobillon. 2004. Spatial wage disparities: Sorting matters! Discussion Paper 4240, Centre for Economic Policy Research.

Cutler, David M., Edward L. Glaeser, and Jesse M. Shapiro. 2003. Why have Americans become more obese? Journal of Economic Perspectives 17(3):93-118.

Durlauf, Steven N. 2004. Neighborhood effects. In Vernon Henderson and Jacques-François Thisse (eds.) Handbook of Regional and Urban Economics, volume 4. Amsterdam: North-Holland, 21732242.

Ewing, Reid, Rolf Pendall, and Don Chen. 2002. Measuring Sprawl and its Impact. Washington, DC: Smart Growth America.

Ewing, Reid, Tom Schmid, Richard Killingsworth, Amy Zlot, and Stephen Raudenbush. 2003. Relationship between urban sprawl and physical activity, obesity, and morbidity. American Journal of Health Promotion 18(1):47-57.

Ezzati, Majid, Hilarie Martin, Suzanne Skjold, Stephen Vander Hoorn, and Christopher J. L. Murray. 2006. Trends in national and state-level obesity in the USA after correction for self-report bias: analysis of health surveys. Journal of the Royal Society of Medicine 99(5):250-257.

Flegal, Katherine M., Margaret D. Carroll, Cynthia L. Ogden, and Clifford L. Johnson. 2002. Prevalence and trends in obesity among us adults, 1999-2000. JAMA-Journal of the American Medical Association 288(14):1723-1727.

Frank, L. D., M. A. Andresen, and T. L. Schmid. 2004. Obesity relationships with community design, physical activity, and time spent in cars. American Journal of Preventive Medicine 27(2):8796.

Gerberding, Julie L. 2003. CDC's role in promoting healthy lifestyles. Statement by Julie L. Gerberding, Director, Centers for Disease Control and Prevention, before the Senate Committee on Appropriations, Subcommittee on Labor, HHS, Education and Related Agencies.

Giles-Corti, B., S. Macintyre, J. P. Clarkson, T. Pikora, and R. J. Donovan. 2003. Environmental and lifestyle factors associated with overweight and obesity in Perth, Australia. American Journal of Health Promotion 18(1):93-102. 
Glaeser, Edward L. and Matthew E. Kahn. 2004. Sprawl and urban growth. In Vernon Henderson and Jacques-François Thisse (eds.) Handbook of Regional and Urban Economics, volume 4. Amsterdam: North-Holland, 2481-2527.

Heckman, James J. and Richard Robb, Jr. 1985. Alternative methods for estimating the impact of interventions. In James J. Heckman and Burton Singer (eds.) Longitudinal Analysis of Labor Market Data. New York, NY: Cambridge University Press, 156-245.

Lakdawalla, Darius and Tomas Philipson. 2002. The growth of obesity and technological change: A theoretical and empirical analysis. Working Paper 8946, National Bureau of Economic Research.

Lakdawalla, Darius, Tomas Philipson, and Jay Bhattacharya. 2005. Welfare-enhancing technological change and the growth of obesity. American Economic Review 95(2):253-257.

McCann, Barbara A. and Reid Ewing. 2003. Measuring the Health Effects of Sprawl: A National Analysis of Physical Activity, Obesity and Chronic Disease. Washington, DC: Smart Growth America.

Mokdad, A. H., M. K. Serdula, W. H. Dietz, B. A. Bowman, J. S. Marks, and J. P. Koplan. 1999. The spread of the obesity epidemic in the United States, 1991-1998. JAMA-Journal of the American Medical Association 282(16):1519-1522.

Plantinga, Andrew J. and Stephanie Bernell. 2005. The association between urban sprawl and obesity: Is it a two-way street? Processed, Oregon State University.

Saelens, B. E., J. F. Sallis, J. B. Black, and D. Chen. 2003. Neighborhood-based differences in physical activity: An environment scale evaluation. American Journal of Public Health 93(9):1552-1558.

Sierra Club. 2000. Sprawl costs us all: How your taxes fuel suburban sprawl. Washington, Dc: Sierra Club.

Sturm, R. 2002. The effects of obesity, smoking, and drinking on medical problems and costs. Health Affairs 21(2):245-253.

Wooldridge, Jeffrey M. 2002. Econometric Analysis of Cross Section and Panel Data. Cambridge, MA: The MIT Press.

World Health Organization. 2003. Obesity and overweight. Fact sheet, World Health Organization. http://www. who.int/dietphysicalactivity/media/en/gsfs_obesity.pdf.

World Health Organization. 2004. Global Strategy on Diet, Physical Activity and Health. Geneva: World Health Organization.

\section{Appendix A. Representativeness of sub-samples}

To estimate our preferred specification (first difference including individual characteristics) we impose a number of sample restrictions. This appendix deals with issues regarding representativeness of the resulting samples. Table 4 reports summary statistics for all variables for the largest possible sample we could use in our various specifications, and shows these are very similar. Tables 5 and 6 show that the restricted sample is also representative in terms of the partial correlations between вмI and the observable characteristics. These tables report the coefficients from the regressions reported in tables 1 and 2 with the only difference being that the oLs specifications are 
Table 4. Summary statistics: various samples

\begin{tabular}{|c|c|c|c|c|c|c|}
\hline \multirow[b]{2}{*}{ Variable } & \multicolumn{3}{|c|}{ Men } & \multicolumn{3}{|c|}{ Women } \\
\hline & [OLS1-OLS2] & [oLs3] & [FD] & [OLS1-OLS2] & [oLs3] & [FD] \\
\hline$\overline{\text { BMI }}$ & $\begin{array}{c}26.000 \\
(4.055)\end{array}$ & $\begin{array}{c}25.977 \\
(4.016)\end{array}$ & $\begin{array}{c}26.138 \\
(4.058)\end{array}$ & $\begin{array}{c}24.562 \\
(5.332)\end{array}$ & $\begin{array}{c}24.544 \\
(5.332)\end{array}$ & $\begin{array}{c}24.688 \\
(5.388)\end{array}$ \\
\hline Residential-sprawl & $\begin{array}{l}0.453 \\
(0.281)\end{array}$ & $\begin{array}{l}0.456 \\
(0.282)\end{array}$ & $\begin{array}{c}0.46 \\
(0.281)\end{array}$ & $\begin{array}{l}0.453 \\
(0.278)\end{array}$ & $\begin{array}{l}0.453 \\
(0.278)\end{array}$ & $\begin{array}{l}0.457 \\
(0.277)\end{array}$ \\
\hline Mixed-use & $\begin{array}{l}0.030 \\
(0.056)\end{array}$ & $\begin{array}{l}0.029 \\
(0.053)\end{array}$ & $\begin{array}{l}0.028 \\
(0.053)\end{array}$ & $\begin{array}{l}0.029 \\
(0.049)\end{array}$ & $\begin{array}{l}0.029 \\
(0.048)\end{array}$ & $\begin{array}{l}0.028 \\
(0.047)\end{array}$ \\
\hline Age & $\begin{array}{c}30.334 \\
(3.069)\end{array}$ & $\begin{array}{c}30.263 \\
(3.032)\end{array}$ & $\begin{array}{c}30.845 \\
(2.836)\end{array}$ & $\begin{array}{c}30.495 \\
(3.062)\end{array}$ & $\begin{array}{c}30.499 \\
(3.059)\end{array}$ & $\begin{array}{c}31.080 \\
(2.866)\end{array}$ \\
\hline Black & $\begin{array}{l}0.120 \\
(0.325)\end{array}$ & $\begin{array}{l}0.118 \\
(0.323)\end{array}$ & $\begin{array}{l}0.117 \\
(0.322)\end{array}$ & $\begin{array}{l}0.127 \\
(0.333)\end{array}$ & $\begin{array}{l}0.122 \\
(0.327)\end{array}$ & $\begin{array}{l}0.120 \\
(0.326)\end{array}$ \\
\hline Hispanic & $\begin{array}{l}0.070 \\
(0.255)\end{array}$ & $\begin{array}{l}0.067 \\
(0.249)\end{array}$ & $\begin{array}{l}0.066 \\
(0.248)\end{array}$ & $\begin{array}{l}0.070 \\
(0.255)\end{array}$ & $\begin{array}{l}0.067 \\
(0.250)\end{array}$ & $\begin{array}{l}0.066 \\
(0.249)\end{array}$ \\
\hline Years schooling & $\begin{array}{c}13.119 \\
(2.486)\end{array}$ & $\begin{array}{c}13.135 \\
(2.468)\end{array}$ & $\begin{array}{c}13.179 \\
(2.479)\end{array}$ & $\begin{array}{c}13.184 \\
(2.371)\end{array}$ & $\begin{array}{c}13.257 \\
(2.342)\end{array}$ & $\begin{array}{c}13.302 \\
(2.354)\end{array}$ \\
\hline Daily smoker & $\begin{array}{l}0.419 \\
(0.493)\end{array}$ & $\begin{array}{l}0.419 \\
(0.493)\end{array}$ & $\begin{array}{l}0.416 \\
(0.493)\end{array}$ & $\begin{array}{l}0.410 \\
(0.492)\end{array}$ & $\begin{array}{l}0.408 \\
(0.492)\end{array}$ & $\begin{array}{l}0.405 \\
(0.491)\end{array}$ \\
\hline Married & $\begin{array}{l}0.541 \\
(0.498)\end{array}$ & $\begin{array}{l}0.533 \\
(0.499)\end{array}$ & $\begin{array}{l}0.549 \\
(0.498)\end{array}$ & $\begin{array}{l}0.607 \\
(0.488)\end{array}$ & $\begin{array}{l}0.611 \\
(0.488)\end{array}$ & $\begin{array}{l}0.623 \\
(0.485)\end{array}$ \\
\hline Working spouse & $\begin{array}{l}0.325 \\
(0.469)\end{array}$ & $\begin{array}{l}0.333 \\
(0.471)\end{array}$ & $\begin{array}{l}0.348 \\
(0.476)\end{array}$ & $\begin{array}{l}0.538 \\
(0.499)\end{array}$ & $\begin{array}{l}0.547 \\
(0.498)\end{array}$ & $\begin{array}{l}0.558 \\
(0.497)\end{array}$ \\
\hline Children in household & $\begin{array}{l}0.821 \\
(1.103)\end{array}$ & $\begin{array}{l}0.797 \\
(1.089)\end{array}$ & $\begin{array}{l}0.844 \\
(1.111)\end{array}$ & $\begin{array}{l}1.283 \\
(1.212)\end{array}$ & $\begin{array}{l}1.262 \\
(1.189)\end{array}$ & $\begin{array}{l}1.312 \\
(1.191)\end{array}$ \\
\hline Newborn & $\begin{array}{l}0.086 \\
(0.281)\end{array}$ & $\begin{array}{l}0.085 \\
(0.279)\end{array}$ & $\begin{array}{l}0.082 \\
(0.274)\end{array}$ & $\begin{array}{l}0.084 \\
(0.278)\end{array}$ & $\begin{array}{l}0.083 \\
(0.276)\end{array}$ & $\begin{array}{l}0.079 \\
(0.270)\end{array}$ \\
\hline Pregnant & & & & $\begin{array}{l}0.050 \\
(0.219)\end{array}$ & $\begin{array}{l}0.051 \\
(0.220)\end{array}$ & $\begin{array}{l}0.048 \\
(0.214)\end{array}$ \\
\hline Annual earnings $(\$ 1,000)$ & $\begin{array}{l}22.836 \\
(17.756)\end{array}$ & $\begin{array}{l}22.756 \\
(17.341)\end{array}$ & $\begin{array}{l}23.902 \\
(17.881)\end{array}$ & $\begin{array}{l}13.040 \\
(12.972)\end{array}$ & $\begin{array}{l}13.408 \\
(12.953)\end{array}$ & $\begin{array}{l}14.016 \\
(13.440)\end{array}$ \\
\hline In work & $\begin{array}{l}0.868 \\
(0.338)\end{array}$ & $\begin{array}{l}0.874 \\
(0.331)\end{array}$ & $\begin{array}{l}0.877 \\
(0.328)\end{array}$ & $\begin{array}{l}0.711 \\
(0.453)\end{array}$ & $\begin{array}{l}0.724 \\
(0.447)\end{array}$ & $\begin{array}{l}0.725 \\
(0.446)\end{array}$ \\
\hline Annual hours worked $(1,000)$ & $\begin{array}{l}2.023 \\
(0.891)\end{array}$ & $\begin{array}{l}2.038 \\
(0.875)\end{array}$ & $\begin{array}{l}2.059 \\
(0.869)\end{array}$ & $\begin{array}{l}1.422 \\
(0.950)\end{array}$ & $\begin{array}{l}1.452 \\
(0.939)\end{array}$ & $\begin{array}{l}1.457 \\
(0.947)\end{array}$ \\
\hline Job strength & $\begin{array}{l}2.648 \\
(0.572)\end{array}$ & $\begin{array}{l}2.649 \\
(0.572)\end{array}$ & $\begin{array}{l}2.636 \\
(0.575)\end{array}$ & $\begin{array}{l}2.033 \\
(0.494)\end{array}$ & $\begin{array}{l}2.029 \\
(0.490)\end{array}$ & $\begin{array}{l}2.022 \\
(0.488)\end{array}$ \\
\hline Job strenuousness & $\begin{array}{l}1.485 \\
(0.595)\end{array}$ & $\begin{array}{l}1.484 \\
(0.592)\end{array}$ & $\begin{array}{l}1.471 \\
(0.593)\end{array}$ & $\begin{array}{l}1.061 \\
(0.388)\end{array}$ & $\begin{array}{l}1.055 \\
(0.384)\end{array}$ & $\begin{array}{l}1.046 \\
(0.382)\end{array}$ \\
\hline Observations & 15427 & 13218 & 10445 & 15926 & 14144 & 11240 \\
\hline Individuals & 2754 & 2599 & 2527 & 2840 & 2713 & 2663 \\
\hline
\end{tabular}

Notes: The table reports the mean and (in parenthesis) the standard deviation of each variable for the largest possible sample available for each specification. These samples correspond to those used to estimate the specifications in the columns with the same headings in tables 5 and 6. 
Table 5. вмI on sprawl and individual characteristics: largest possible sample — Men

\begin{tabular}{|c|c|c|c|c|}
\hline Variable & [OLS1] & [OLS2] & [oLs3] & [FD] \\
\hline Residential-sprawl & $\begin{array}{l}0.398 \\
(0.252)\end{array}$ & $\begin{array}{c}0.567 \\
(0.253)^{* *}\end{array}$ & $\begin{array}{c}-0.143 \\
(0.266)\end{array}$ & $\begin{array}{c}-0.042 \\
(0.119)\end{array}$ \\
\hline Mixed-use & $\begin{array}{l}-2.303 \\
(1.031)^{* *}\end{array}$ & $\begin{array}{l}-3.247 \\
(1.003)^{* * *}\end{array}$ & $\begin{array}{l}-2.578 \\
(1.095)^{* *}\end{array}$ & $\begin{array}{l}0.497 \\
(0.663)\end{array}$ \\
\hline Age & & $\begin{array}{c}0.817 \\
(0.207)^{* * *}\end{array}$ & $\begin{array}{c}0.812 \\
(0.228)^{* * *}\end{array}$ & $\begin{array}{c}0.585 \\
(0.144)^{* * *}\end{array}$ \\
\hline Age $^{2}$ & & $\begin{array}{l}-0.011 \\
(0.003)^{* * *}\end{array}$ & $\begin{array}{l}-0.011 \\
(0.004)^{* * *}\end{array}$ & $\begin{array}{l}-0.006 \\
(0.002)^{* * *}\end{array}$ \\
\hline Black & & $\begin{array}{c}0.555 \\
(0.221)^{* *}\end{array}$ & $\begin{array}{c}0.658 \\
(0.240)^{* * *}\end{array}$ & \\
\hline Hispanic & & $\begin{array}{c}1.762 \\
(0.360)^{* * *}\end{array}$ & $\underset{(0.361)^{* * *}}{1.228}$ & \\
\hline Years schooling & & & $\begin{array}{l}-0.152 \\
(0.040)^{* * *}\end{array}$ & $\begin{array}{l}0.081 \\
(0.054)\end{array}$ \\
\hline Daily smoker & & & $\begin{array}{l}-1.008 \\
(0.169)^{* * *}\end{array}$ & $\begin{array}{c}-0.119 \\
(0.185)\end{array}$ \\
\hline Married & & & $\begin{array}{l}0.184 \\
(0.180)\end{array}$ & $\begin{array}{c}0.322 \\
(0.064)^{* * *}\end{array}$ \\
\hline Working spouse & & & $\begin{array}{l}0.273 \\
(0.145)^{*}\end{array}$ & $\begin{array}{c}-0.030 \\
(0.037)\end{array}$ \\
\hline Children in household & & & $\begin{array}{l}0.112 \\
(0.083)\end{array}$ & $\begin{array}{l}0.009 \\
(0.037)\end{array}$ \\
\hline Newborn & & & $\begin{array}{c}-0.144 \\
(0.128)\end{array}$ & $\begin{array}{l}0.070 \\
(0.045)\end{array}$ \\
\hline In work & & & $\begin{array}{l}-0.346 \\
(0.161)^{* *}\end{array}$ & $\begin{array}{l}-0.139 \\
(0.053)^{* * *}\end{array}$ \\
\hline Annual hours worked $(1,000)$ & & & $\begin{array}{c}0.225 \\
(0.083)^{* * *}\end{array}$ & $\begin{array}{l}-0.056 \\
(0.030)^{*}\end{array}$ \\
\hline Annual earnings $(\$ 1,000)$ & & & $\begin{array}{c}-0.002 \\
(0.004)\end{array}$ & $\begin{array}{l}0.001 \\
(0.001)\end{array}$ \\
\hline Job strength & & & $\begin{array}{c}1.108 \\
(0.287)^{* * *}\end{array}$ & $\begin{array}{c}-0.168 \\
(0.309)\end{array}$ \\
\hline Job strenuousness & & & $\begin{array}{l}-0.697 \\
(0.275)^{* *}\end{array}$ & $\begin{array}{l}0.052 \\
(0.292)\end{array}$ \\
\hline Observations & 15427 & 15427 & 13218 & 10445 \\
\hline Individuals & 2754 & 2754 & 2599 & 2527 \\
\hline$R^{2}$ & 0.02 & 0.04 & 0.07 & 0.05 \\
\hline
\end{tabular}

Notes: The dependent variable is BMI. OLS1, OLS2, and OLS3 are estimated pooling data over all years, while FD is estimated in first differences. Year dummies are included in all specifications. Numbers in parenthesis report clustered standard errors. ${ }^{* *},{ }^{* *}$, and ${ }^{*}$ indicate significance at the $1 \%, 5 \%$ and $10 \%$ level, respectively. 
Table 6. BMI on sprawl and individual characteristics: largest possible sample - Women

\begin{tabular}{|c|c|c|c|c|}
\hline Variable & [OLSI] & [OLS2] & [OLS3] & [FD] \\
\hline$\overline{\text { Residential-sprawl }}$ & $\begin{array}{l}0.025 \\
(0.352)\end{array}$ & $\begin{array}{c}0.578 \\
(0.334)^{*}\end{array}$ & $\begin{array}{c}-0.105 \\
(0.345)\end{array}$ & $\begin{array}{c}-0.154 \\
(0.135)\end{array}$ \\
\hline Mixed-use & $\begin{array}{l}0.873 \\
(2.180)\end{array}$ & $\begin{array}{c}-2.198 \\
(1.755)\end{array}$ & $\begin{array}{c}-0.731 \\
(1.771)\end{array}$ & $\begin{array}{c}-0.473 \\
(0.640)\end{array}$ \\
\hline Age & & $\begin{array}{c}0.551 \\
(0.262)^{* *}\end{array}$ & $\begin{array}{c}0.815 \\
(0.287)^{* * *}\end{array}$ & $\begin{array}{c}0.527 \\
(0.186)^{* * *}\end{array}$ \\
\hline Age $^{2}$ & & $\begin{array}{r}-0.007 \\
(0.004)\end{array}$ & $\begin{array}{l}-0.011 \\
(0.005)^{* *}\end{array}$ & $\begin{array}{l}-0.005 \\
(0.003)^{*}\end{array}$ \\
\hline Black & & $\begin{array}{c}3.512 \\
(0.323)^{* * *}\end{array}$ & $\begin{array}{c}2.933 \\
(0.355)^{* * *}\end{array}$ & \\
\hline Hispanic & & $\begin{array}{c}1.952 \\
(0.416)^{* * *}\end{array}$ & $\begin{array}{c}1.326 \\
(0.430)^{* * *}\end{array}$ & \\
\hline Years schooling & & & $\begin{array}{c}-0.254 \\
(0.048)^{* * *}\end{array}$ & $\begin{array}{l}0.024 \\
(0.059)\end{array}$ \\
\hline Daily smoker & & & $\begin{array}{l}-0.845 \\
(0.207)^{* * *}\end{array}$ & $\begin{array}{c}-0.301 \\
(0.224)\end{array}$ \\
\hline Married & & & $\begin{array}{l}0.040 \\
(0.298)\end{array}$ & $\begin{array}{c}0.435 \\
(0.097)^{* * *}\end{array}$ \\
\hline Working spouse & & & $\begin{array}{c}-0.121 \\
(0.238)\end{array}$ & $\begin{array}{l}0.077 \\
(0.068)\end{array}$ \\
\hline Children in household & & & $\begin{array}{c}-0.019 \\
(0.098)\end{array}$ & $\begin{array}{l}0.054 \\
(0.061)\end{array}$ \\
\hline Newborn & & & $\begin{array}{c}0.532 \\
(0.156)^{* * *}\end{array}$ & $\begin{array}{c}0.592 \\
(0.064)^{* * *}\end{array}$ \\
\hline Pregnant & & & $\begin{array}{c}1.833 \\
(0.197)^{* * *}\end{array}$ & $\begin{array}{c}1.882 \\
(0.096)^{* * *}\end{array}$ \\
\hline In work & & & $\begin{array}{c}-0.067 \\
(0.153)\end{array}$ & $\begin{array}{l}-0.170 \\
(0.053)^{* * *}\end{array}$ \\
\hline Annual hours worked $(1,000)$ & & & $\begin{array}{c}0.370 \\
(0.097)^{* * *}\end{array}$ & $\begin{array}{c}-0.047 \\
(0.032)\end{array}$ \\
\hline Annual earnings $(\$ 1,000)$ & & & $\begin{array}{l}-0.030 \\
(0.008)^{* * *}\end{array}$ & $\begin{array}{c}-0.003 \\
(0.002)\end{array}$ \\
\hline Job strength & & & $\begin{array}{c}0.698 \\
(0.288)^{* *}\end{array}$ & $\begin{array}{c}-0.491 \\
(0.315)\end{array}$ \\
\hline Job strenuousness & & & $\begin{array}{c}0.757 \\
(0.404)^{*}\end{array}$ & $\begin{array}{l}0.343 \\
(0.320)\end{array}$ \\
\hline Observations & 15926 & 15926 & 14144 & 11240 \\
\hline Individuals & 2840 & 2840 & 2713 & 2663 \\
\hline$R^{2}$ & 0.01 & 0.06 & 0.1 & 0.11 \\
\hline
\end{tabular}

Notes: The dependent variable is BMI. OLS1, OLS2, and OLS3 are estimated pooling data over all years, while FD is estimated in first differences. Year dummies are included in all specifications. Numbers in parenthesis report clustered standard errors. ${ }^{* *},{ }^{* *}$, and ${ }^{*}$ indicate significance at the $1 \%, 5 \%$ and $10 \%$ level, respectively. 
Table 7. вмI on residential-sprawl, mixed-use and individual characteristics (sub-samples)

\begin{tabular}{|c|c|c|c|c|c|c|c|c|}
\hline & Variable & [OLSI] & [OLS2] & [OLs3] & [FD] & [R1] & [R2] & [R3] \\
\hline \multicolumn{9}{|l|}{$\overline{\text { Men }}$} \\
\hline & SGA index & $\begin{array}{c}-0.004 \\
(0.002)\end{array}$ & $\begin{array}{l}-0.006 \\
(0.002)^{* *}\end{array}$ & $\begin{array}{c}-0.004 \\
(0.003)\end{array}$ & $\begin{array}{l}0.001 \\
(0.002)\end{array}$ & $\begin{array}{l}0.001 \\
(0.002)\end{array}$ & $\begin{array}{c}0.010 \\
(0.005)^{*}\end{array}$ & $\begin{array}{l}0.001 \\
(0.003)\end{array}$ \\
\hline & Observations & 8915 & 8915 & 8103 & 6281 & 4271 & 414 & 2472 \\
\hline & Individuals & 1684 & 1684 & 1684 & 1684 & 1157 & 414 & 663 \\
\hline & $R^{2}$ & 0.02 & 0.03 & 0.07 & 0.05 & 0.05 & 0.35 & 0.04 \\
\hline \multicolumn{9}{|c|}{ Women } \\
\hline & SGA index & $\begin{array}{l}0.002 \\
(0.004)\end{array}$ & $\begin{array}{c}-0.006 \\
(0.004)\end{array}$ & $\begin{array}{c}-0.003 \\
(0.004)\end{array}$ & $\begin{array}{l}0.001 \\
(0.002)\end{array}$ & $\begin{array}{l}0.000 \\
(0.002)\end{array}$ & $\begin{array}{l}0.001 \\
(0.004)\end{array}$ & $\begin{array}{l}0.002 \\
(0.002)\end{array}$ \\
\hline & Observations & 9386 & 9386 & 8763 & 6839 & 4547 & 590 & 2311 \\
\hline & Individuals & 1780 & 1780 & 1780 & 1780 & 1199 & 590 & 611 \\
\hline & $R^{2}$ & 0.01 & 0.07 & 0.11 & 0.12 & 0.12 & 0.29 & 0.04 \\
\hline
\end{tabular}

Notes: The dependent variable is BMI. OLS1, OLS2, and OLS3 are estimated by pooling data over all years. OLS1 includes no individual controls. OLS2 controls for age, age $^{2}$, and race. oLs3 includes the full set of individual controls. FD, R1, R2, $\mathrm{R} 3$ are estimated in first differences. FD uses the full sample of movers and non-movers. R1 restricts the sample of movers to individuals who experience large changes in their neighborhood characteristics. R2 restricts the sample of movers to individuals who only move once and in either 1990 or 1992 and uses long-differences. R3 restricts the sample of movers to individuals who do not experience a change in marital status or child-related variables. Year dummies are included in all specifications. Numbers in parenthesis report clustered standard errors. ${ }^{* * *},{ }^{* *}$, and ${ }^{*}$ indicate significance at the $1 \%, 5 \%$ and $10 \%$ level, respectively.

now estimated for the largest possible sample. Comparing across the two sets of tables, we see that (as discussed in the text) imposing the sample restriction only marginally affects the significance of the coefficient on sprawl for women in regression ols2. Moving from a partial to a full set of controls, we see that results are identical across the full and restricted samples. Taken together, these summary statistics and supplementary regressions show that our main results are not driven by the sample restrictions that we impose to calculate our first difference specification.

\section{Appendix B. Results using Smart Growth America Sprawl Index}

This paper differs from most existing studies of obesity anbd sprawl in two regards.

As discussed in the text, relative to a number of existing studies we have changed both the method of estimation and the definition of the neighborhood variables. Results reported in this appendix show that we reach the same conclusions regarding the effect of sprawl on BMI if we estimate the same set of specifications using the same sprawl index as Ewing et al. (2003). Thus, table 7 reports estimates for the main specifications discussed in the text but uses an alternative measure of sprawl: the index provided by Smart Growth America (sGA) (Ewing et al., 2002). The labelling of columns is identical to those in the text. Thus, OLS1 provides the raw correlation; ols2 the coefficients after introducing a partial set of demographic controls; oLs 3 the coefficient after allowing for a full set; FD the first difference results that allow for unobserved propensity to be obese; RI the results when we only consider the sub-sample of movers that experience large changes in neighborhoods; 22 the results when we only consider the sub-sample of individuals that move one and $\mathrm{R} 3$ the results when we only consider the sub-sample of individuals that experience no major life-cycle changes. See the main text for further discussion of each of these specifications. 
Before considering the results, note that the SGA index is defined such that large numbers represent 'smart' (i.e. non-sprawling) neighborhoods. Thus, a negative correlation between the index and BMI is consistent with a positive correlation between sprawl and obesity. Comparing results with the relevant specifications from tables 1, 2 and 3 we get essentially identical results for both men and women. Interestingly, for men, results for oLs3 (ols including a full set of controls) for our two variables showed no effect for residential-sprawl, but a significant effect for mixed-use. Results for the compound SGA index show a negative correlation, but it is just insignificant (it is significant at the $10.3 \%$ level). This is in line with our observation in section 2 that such indices are hard to interpret when they are constructed as an average of several variables that are known to be weakly correlated with each other (Glaeser and Kahn, 2004, Burchfield et al., 2006). Once we control for individuals' unobserved propensity to be obese in the FD specification, the coefficient on the SGA index is not statistically significant. The robustness checks work as with our neighborhood variables - once again, in the first difference regressions only the R2 specification shows a statistically significant coefficient on the neighborhood variable, and it runs contrary to the existing literature: men in this particular sub-sample who move to a neighborhood with less sprawl (higher SGA index) tend to see their weight increase.

Overall, we reach the same conclusions regarding the effect of sprawl on BMI if we estimate the same set of specifications using the Smart Growth America index of sprawl instead of our two landscape variables. The key point is that, once again, there is no evidence of a causal relationship between neighborhood and weight once we control for unobserved propensity to be obese. 